\title{
CHALLENGES OF RAISING ROAD MAINTENANCE FUNDS IN DEVELOPING COUNTRIES: AN ANALYSIS OF ROAD TOLLING IN ZIMBABWE
}

\author{
T. C. MBARA \\ M. NYARIRANGWE* \\ T. MUKWASHI** \\ tmbara@uj.ac.za \\ University of Johannesburg \\ South Africa \\ *maxwelln@ssi.co.za \\ SSI Engineers, Pretoria, South Africa \\ **tapmukwashi@yahoo.co.uk \\ Netherlands Maritime University, World Marine Centre, Korea
}

\begin{abstract}
The condition of Zimbabwe's roads has been declining due to insufficient maintenance and rehabilitation. Year on year, budget allocations have compared unfavourably with funding considered adequate to maintain highway networks and conduct modest construction work. Road infrastructure shortcomings have manifested themselves in the form of high vehicle operating costs and rampant potholes, leading to a decline in road safety and a deterioration of service levels for those who use roads to deliver goods or connect to international markets. In order to try and stop this vicious cycle of decline, the Government of Zimbabwe, on 8 August 2009, introduced a new policy of road-user charges, which involved the setting-up of 22 toll gates on the trunk road network. The overall objective was to raise revenue in order to close the funding gap, blamed for declining road quality. Although alternative methods of financing road maintenance have been debated for years, a generally accepted understanding is that road users should pay costs for road provisioning. This paper assesses the implementation of a road tolling system in Zimbabwe and describes matters relating to, inter alia, implementation strategy, initial performance outcomes and sustainability.
\end{abstract}

\section{INTRODUCTION}

The main source of funding for road infrastructure in developing countries has traditionally comprised direct government allocation, through Public Sector Investment Programmes (PSIP), vehicle licences and fuel levies. However, due to the paucity of funds from these sources, governments are increasingly considering applying the road-user pay principle, which involves motorists paying a fee (toll) for driving on a particular road. An ideal implementation of this principle prescribes that road users need to have the option of using alternative transit routes, to fulfil the requirement for choice and fairness in infrastructure 
provision. For countries in the developed world that have introduced road tolling, the strategy was meant to generate revenue for road infrastructure financing and, secondly, to control traffic flows through demand management.

Faced with a dire need to raise funds for road maintenance, the Government of Zimbabwe, on 8 August 2009, introduced toll fees on its regional trunk road network. This was done through the gazetting of Statutory Instrument 39 of 2009 cited as the Toll Roads (Regional Trunk Road Network) (Amendment) Regulations No 1 (Government of Zimbabwe, 2009). A total of 22 toll collection centres was set up on the country's trunk and regional routes. In announcing the new approach to generating revenue for road maintenance, the Minister of Transport, Communications and Infrastructural Development outlined the policy triggers and need for government to act quickly to save roads from total collapse. Visible potholes and a high fatality rate along the trunk roads provided adequate justification and urgency for introducing the road toll charges.

Before introducing these toll roads, no feasibility study was undertaken to objectively assess the project's viability. There have, thus, been conflicting opinions on the feasibility and objectives of the new measure. While the public has viewed the introduction of toll roads with general suspicion, the government has heralded them as an imaginative, prudent and timely intervention strategy. There is thus considerable variance and divergent thought in understanding Zimbabwe's new road management approach.

This paper is meant to provide insights into the challenges of raising road maintenance funds through road-user charges by examining the Zimbabwean case. In analysing the new policy measure, an attempt is made to draw comparisons between theoretical prescriptions for implementing a tolling strategy and the actual steps that were taken in establishing the policy in Zimbabwe. Researchers sought to assess the validity of the underlying assumptions used in designing the proposed solution to securing funds for road maintenance. To achieve this, the paper provides a brief background on the environment in which toll policy has been designed and implemented. A discussion based on available literature on tolling follows, which draws on the experiences of other countries. An outline of the methods used to gather information required for this paper is provided. This is followed by a discussion of research findings. A description of the current state of toll implementation efforts are benchmarked against recommendations from the principles guiding the design of toll systems. The paper concludes with an evaluation of the sustainability of the policy measure.

\section{Background}

Zimbabwe has a road network of $85000 \mathrm{~km}$, comprising surfaced, gravel and earth roads. Approximately $8900 \mathrm{~km}$ of the total network constitutes the primary and regional trunk road network. The average age of the regional trunk road network is over 40 years and many 
roads have outlived their design life and are in need of rehabilitation (Gumbie \& Kudenga, 2009). The overall quality of the country's road infrastructure has continued to deteriorate over the years, as characterised by visible structural failures and associated fatalities along most of the trunk network. The World Bank (2006) estimated that only about $24 \%$ of the total network is still in good condition, while over $40 \%$ is in a very poor condition.

The gradual deterioration in road quality has largely been attributed to insufficient funding for maintenance and rehabilitation. According to Gumbie and Kudenga (2009), a World Bank mission pointed out that, whereas the total road maintenance funding requirement in 2005 was about US\$160 million, only US\$10 million, amounting to 6\% of the requirement, was provided. In 2009, the estimated funding requirement for road maintenance amounted to about US $\$ 225$ million compared to a budget provision of US\$13 million, which was less than $6 \%$ of the total required amount. The road rehabilitation requirements were estimated at about $\$ 1.3$ billion, compared to a budget allocation of $\$ 8$ million, a mere $0.6 \%$ of the total need. Consequently, the quality of the road network has continued to deteriorate. Progressively higher funding is required to restore it to an acceptable quality.

To date, the infrastructure has deteriorated to such an extent that the public is being seriously inconvenienced, while the normal functioning of businesses has been severely affected. Figures 1 and 2 illustrate the extent of deterioration of the trunk road infrastructure. There is general consensus among local communities, public and private institutions that the vital national grid has deteriorated beyond any acceptable minimal standard socially, economically and environmentally. There has, thus, been much interest and anxiety in relation to the new road management approach that has been introduced by the government. This strategy is founded on the application of the user-pay principle to accrue funding for maintenance and construction of road infrastructure.

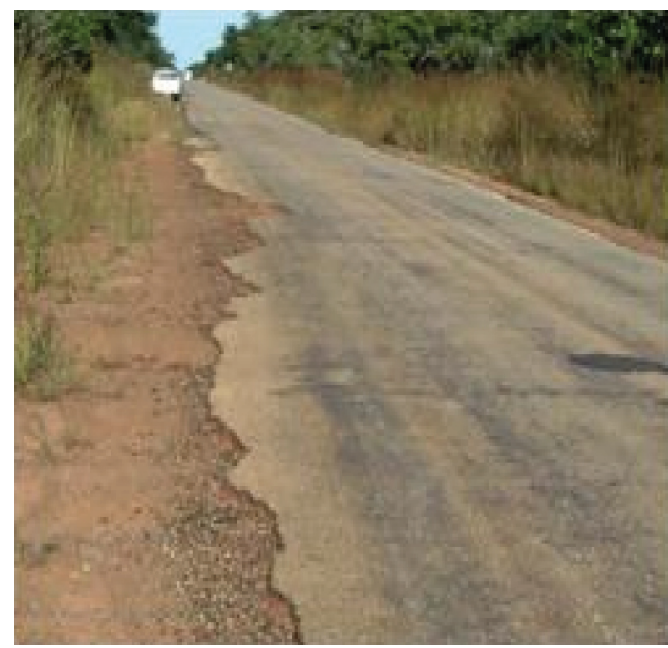

Figure 1:

Fracturing along the edge

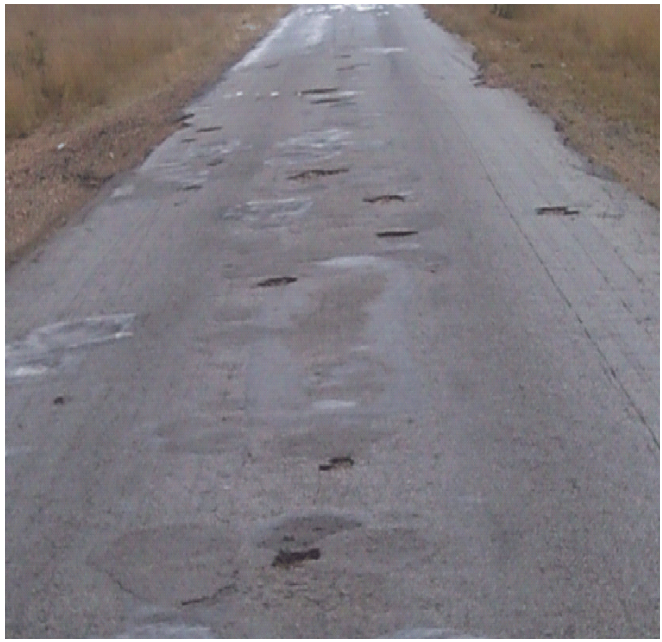

Figure 2:

Potholes on trunk road pavement

(Source: Gumbie \& Kudenga [2009]) 
Although road tolling is being applied on a first trial basis in Zimbabwe, Silva (2000) pointed out that it has always been in existence in Europe, the USA, Latin America and Asia. Khan (2009) concurred by highlighting that the scale of interest in toll facilities, internationally, is unprecedented, as it has even been extended to the level of toll lanes. In sub-Saharan Africa, it has been extensively used only in South Africa. While the global trend has mainly focused on privately run toll systems using the build, operate and transfer (BOT) approach, the Zimbabwean government has opted for a state-controlled approach.

\section{Rationale for the evaluation of the national toll project}

There has been much public interest and many unanswered questions regarding, mainly, the objectives and feasibility of the new tolling system. This has necessitated an evaluation of the road tolling strategy's suitability for Zimbabwe. This is important in order to evaluate the social, economic and environmental impacts, as well as the initial outcomes of the toll operations.

The key objective of the toll projects is to achieve acceptable levels of service in terms of improved safety and efficiency along the road network. It also focuses on lowering travel and vehicle operating costs as well as accident rates. Road accidents occurring on trunk roads are largely attributed to the poor state of the road network. Many lives are being lost as drivers lose control of their vehicles in attempts to negotiate and avoid potholes. The government has, therefore, accepted that an improvement in the quality of the country's trunk road network is critical in alleviating the situation. However, given the dwindling financial resources, the introduction of innovative methods, such as road tolling, has become urgent.

It is notable, however, that in the long term many outcomes are possible from implementing a tolling system. At worst the entire project will crumble due to overwhelming operation costs that cannot be recovered from available traffic volumes. It is also possible that public discontent, if no visible improvements are achieved, may shift the political opinion and ultimately policy, sealing the fate of an otherwise promising strategy. At best the toll system may generate revenue sufficient to halt the decline in road quality levels. Because of the possibility of failed outcomes, there is a need to identify challenges in the project to enable the design of objective solutions. In this way, administrative opinion can be shaped so that policy-makers avoid engaging in the science of muddling through on a project of strategic national importance such as a tolling strategy.

\section{LITERATURE REVIEW}

Transportation funding, particularly in developing countries, has traditionally been the responsibility of the government. Experience across the world has proven that the capacity of most governments to adequately fund transport infrastructure construction and maintenance is limited. The challenge has been exacerbated by the fact that transport 
infrastructure provisioning competes strongly for funding with other sector needs such as water, health, education, housing, etc. Therefore, a number of innovative fund-raising projects, as well as partnerships with, particularly, the private sector, have continued to be researched and implemented.

The South African National Department of Transport (NDoT) (NDoT 2009) recommends that the choice among different transport funding methods should be based on a number of parameters including equitability, efficiency, adequacy and ease of administration. This is fundamental, although it is rare to find any source of funding that fulfils all these criteria at the same time. The main sources of road (construction and maintenance) funds that are common in many countries include fuel levy, motor vehicle licences and road tolling among others. In other countries like South Africa, funds in the form of conditional and other grants are transferred from the National Treasury to the road agency. The Provincial Department of Transport also provides funding in the form of municipal infrastructure grants (NDoT, 2009).

Despite various innovative efforts, private sector participation in transportation capital and operational investment remains limited. Research shows that while transitional countries are expected to spend at least 5\% of GDP on road infrastructure, most developing countries are currently spending about 2\% (Metschies \& Rausch, 1991; Gwilliam \& Shalizi, 1996; Kuang \& Shladover, 2006; Queiroz, Rdzanowska, Garbarczyk \& Audige, 2008). This scenario indicates that road systems are generally underfunded. The NDoT (2009) reports that in South Africa, the National Treasury transfers over $95 \%$ of provincial revenue requirements for the construction and maintenance of road infrastructure.

Given the limitations associated with the funding sources, most governments are pursuing the option of involving the private sector, through different forms of public-private partnerships (PPPs). Forces driving the different forms of partnerships include the associated acceleration of infrastructure provision, faster implementation, reduced whole life cost, better risk allocation, better incentives to perform, improved quality of services, generation of additional revenues, and enhanced public management. The most common of such partnerships include service contracts, management contracts, leases, BOT, concessions and divestiture (full-scale privatisation). These options exhibit different levels of public and private sector involvement and responsibilities. The greatest public and private sector involvement is found under service contracts and divestiture, respectively.

Road tolling evolved largely on a trial-and-error basis. Early toll systems were called turnpike roads, with the first of these having been authorised in 1663 for a section of the Great North Road in England (Coleman, 2006). These early toll systems involved the establishment of 20-year trustees, whose responsibility was to construct gates and demand statute labour or cash, in return for repairing roads and erecting mileposts. In the United States of America 
(USA), the first toll road was a Pennsylvania turnpike, which was chartered in 1792. The number of similar projects increased rapidly until the 19th century (Jones \& Bekmez, 2001; Coleman, 2006). Generally, these systems were not well received by residents, who were used to free use of road systems.

The progress to better roads has seldom been a smooth one for most countries. Fishbein and Babbar (1996) studied the experiences of eight road toll projects in developing and industrialised countries. Their study examined financing of toll roads and public-private partnerships. They concluded that the success of toll projects is dependent on an efficient allocation of responsibilities between the public and private sectors. Out of the eight countries, Chile, Colombia, Hungary, United Kingdom, and the United States scored high in terms of concession environment. On the other hand China, Mexico and Malaysia were considered to have less favourable environments and, therefore, recorded lower service levels in their projects.

Parasibu (2005) discussed the impact of toll roads on regional development in Jabotabek, the largest urban area in Indonesia. He emphasised the importance of private capital in the development of toll roads. Since the government's fiscal capacity is limited, private capital increases the opportunity for road development. He also found that an improved road network is critical in facilitating the development of industry, creating and expanding residential areas, and implementing environmental improvements. Significant improvements in the transportation system also led to increased land values. His research concluded that the toll road system resulted in increased private investment and stimulation of socioeconomic and regional development.

Spry and Crowley (2004) cautioned that many factors contribute to the quality and efficiency of toll roads. They argued that a government-created monopoly for service provision increases prices and decreases the quality of services, reducing overall consumer welfare. To avoid failure in toll projects, they recommended the removal of exclusive operating rights of governments to improve customer well-being along the toll roads.

According to global ratings, toll roads as an asset class have been subject to relatively low default rates. However, some toll projects have been subject to periods of distress, largely due to poor forecasting of initial traffic and revenue performance. In the more stable and developed economies, incorrect predictions and project externalities caused downgrades, debt restructuring, workouts and payment defaults. In developing economies, the added risk of economic cyclicality has similarly caused downgrades and defaults. In countries without a history of toll roads, affordability and the willingness to pay have affected project viability.

Poole and Moore (2006) envisaged a brighter future and an increase in the use of tolling systems. They pointed out that the long-term viability of fuel tax as a principal source of 
highway funding is on the decline. While such taxation will remain the principal funding source for the medium term, its long-term viability is highly questionable. This is due to a variety of trends and possibilities, such as rising oil prices, stringent fuel-economy regulations, legislative and regulatory measures aimed at reducing greenhouse gases, and the potential success of extensive research into alternative propulsion technologies. Therefore, it can be expected that toll systems in their various forms are likely to be the most feasible road pricing strategies for the future.

Tolling has been used both as a revenue-generating method and traffic management tool. As a traffic management measure, tolling of congested routes assists in discouraging travellers from using the tolled route or riding low-occupancy vehicles. Travellers will be forced to use high occupancy transport modes such as public transport and pool cars. According to Yang and Qui (2005), the application of tolling as a traffic management tool successfully reduced peak traffic volumes from 40000 to 15000 vehicles along highways in Singapore. Despite the achievements in Singapore and other countries across the world, experience has also shown that traffic problems often result from complex interactions between the vehicles, infrastructure, users and surrounding environments. Therefore traffic management strategies should not be focused around one method such as road tolling. Ideally, a thorough problemstructuring exercise should be done in order to streamline a combination of measures that can be implemented to holistically address the traffic challenges.

In implementing a toll strategy, Khan (2009) recommended a rational planning process illustrated in Figure 3. The planning sequence serves the purpose of ensuring that due consideration is given to all important elements in toll system design.

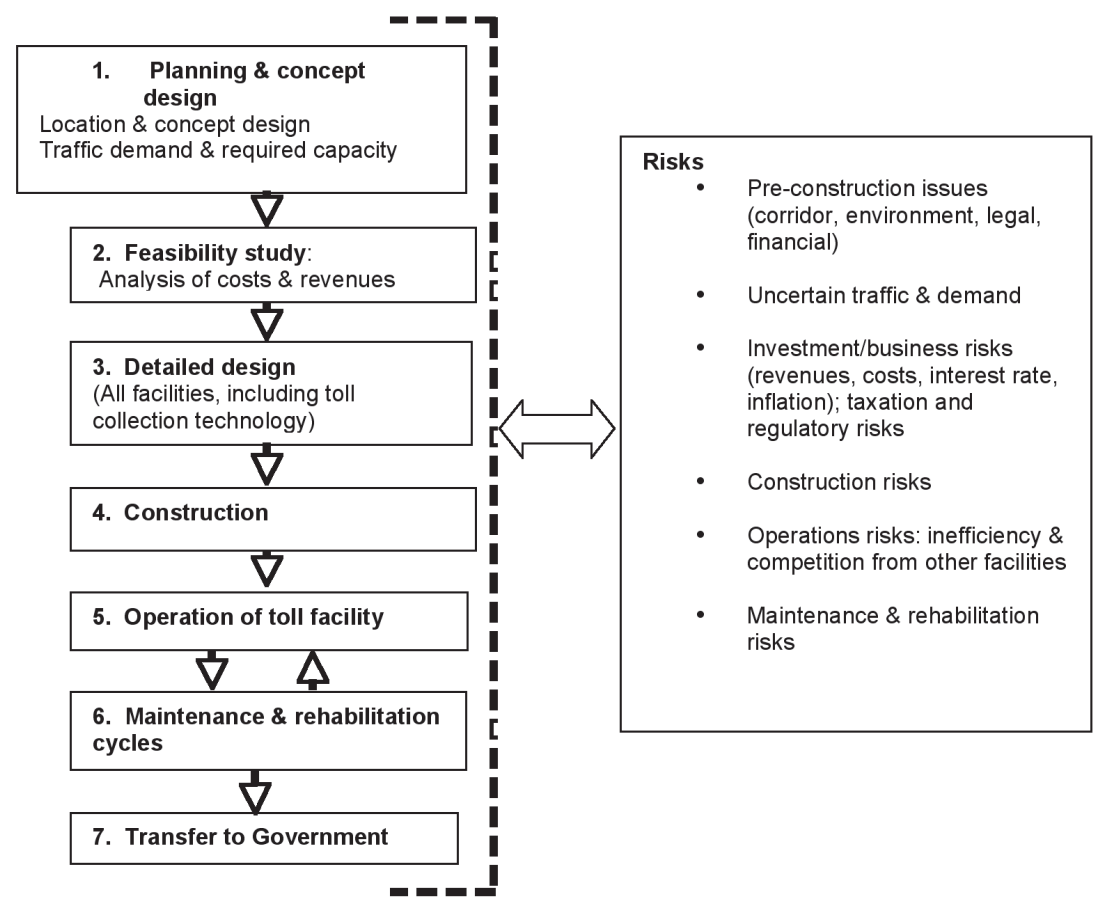

Figure 3: Toll roads planning process (Source: Khan [2009]) 
Khan (2009) emphasises the need for a feasibility study stating that there are associated risks that need to be identified and managed prior to the toll system implementation. The common risks that have been identified globally include pre-construction issues such as environmental problems, opposition from special interest groups, arranging finance for the project, uncertainty of traffic volumes, business and regulatory risks.

\section{RESEARCH STRATEGY}

\section{Research approach}

The evaluation of projects which have a considerable impact on whole communities requires public involvement. As a result, appropriate tools must be developed to capture the wider public opinion. This specific requirement underpins the evaluation methods for transportation projects, as the benefits and costs are estimated from societal points of view. There is no universal way to collect public opinion and, hence, there will thus be disagreements as to whether all or the right opinions were captured. Notwithstanding this limitation, the following approaches were used in gathering the relevant information for this paper. The research adopted a triangulation of techniques to capture as much information as possible, since road tolling is still a new phenomenon in Zimbabwe. The main methods that were used are explained below.

\section{Direct observations}

Random sampling methods were applied in selecting toll facilities for observation. There is relative standardisation in the toll structures which makes generalisation from observations possible. Observations were conducted on 12 sites to establish the activities and operations at the toll facilities. Issues such as available infrastructure, human resource composition and quantities, average dwell times for vehicles, operational issues to do with challenges associated with the use of multiple currencies, etc, were observed and documented.

\section{Structured and unstructured discussions with relevant organisations}

The research sought to establish an overall impression of the system. Thus, institutions that are involved in making day-to-day decisions regarding the operation of the toll system were consulted. The objective was to establish responsibilities, traffic volumes, methods of cash collection and transfers, transaction costs involved and other operational challenges. An open-ended structured questionnaire was used together with unstructured discussions. This mainly involved officers from the Zimbabwe National Roads Authority (ZINARA), Ministry of Transport, Infrastructure and Communications (MoTIC), and the Zimbabwe Revenue Authority (ZIMRA), although the latter were not forthcoming with information.

\section{Archive information}

Progress in the development of toll gates has received wide coverage from the national media. As such, the researchers looked into the media archives, related past government policy documents and other pronouncements to trace all relevant information that could 
shed more light on the toll system. These were critical, since no strategic document was issued by the relevant authorities explaining the objectives and operations of the toll system. Newspapers enabled the researchers to track the Minister's policy pronouncements as well as views of road users and the general public.

\section{Analytical review}

Based on the information collected from various sources, researchers conducted an analysis to note trends and consistency, in order to get an overall impression of the systems design. In doing so, both positive and negative aspects in the toll system and its implementation were unearthed. While accepting that there is no universal framework for the planning, design, construction, operations and maintenance of toll systems, researchers, however, sought to find out which best practice the government was benchmarking its 'new' toll strategy on.

\section{Evaluation criteria}

In assessing the tolling system, the study was guided by criteria which are summarised in Table I below. The two sections on Findings and Discussion will endeavour to provide answers to questions raised in the evaluation criteria.

Table I: Criteria used to evaluate the road tolling system

\begin{tabular}{|c|c|}
\hline Category & Evaluation criteria \\
\hline Effectiveness & $\begin{array}{l}\text { - What proportion of the total revenue goes to secondary costs? } \\
\text { - To what extent do toll fees affect average household monthly expenditure? } \\
\text { - How effective is the tolling system in comparison with other revenue-generating systems currently } \\
\text { in place? }\end{array}$ \\
\hline Efficiency & $\begin{array}{l}\text { - Is the design of the toll system based on rational planning principles? } \\
\text { - Is the tolling system compatible with technology, e.g. credit cards, debit cards } \\
\text { - Is toll fee collection system efficient (labour component)? } \\
\text { - Does the toll system have acceptable toll station dwell times? }\end{array}$ \\
\hline Viability & $\begin{array}{l}\text { - Do the toll gates have sufficient traffic volumes to justify the investment? } \\
\text { - What proportion of the total traffic volume is exempted? } \\
\text { - Are the charges viable i.e. how do they compare with toll charges elsewhere? } \\
\text { - Are there any leakage challenges associated with the toll facility operations? }\end{array}$ \\
\hline Equity & $\begin{array}{l}\text { - Will the toll system distribute costs and benefits equally to all segments of the population within } \\
\text { the service area? } \\
\text { - To what extent do toll fees affect average household monthly disposable income levels? } \\
\text { - Are the toll gates located sufficiently beyond the average commuting radii of cities and towns? If } \\
\text { not are there any mechanisms to subsidise commuters who pass through the toll gates daily? } \\
\text { - Are there any mechanisms to subsidise HOVs such as buses and other public transport vehicles? }\end{array}$ \\
\hline Safety & $\begin{array}{l}\text { - Does the system meet requirements provided under the Health and Safety Act? } \\
\text { - Are there any safety hazards for officers manning the stations? If so what mitigation measures have } \\
\text { been put in place to protect them? } \\
\text { - Are there any environmental hazards associated with the toll facilities }\end{array}$ \\
\hline $\begin{array}{l}\text { Ease of } \\
\text { administration }\end{array}$ & $\begin{array}{l}\text { - Have the concerned stakeholders been consulted in drafting the implementation guidelines? } \\
\text { - Is the institutional set-up ideal for operating and administering the system? } \\
\text { - What are the transaction costs associated with the institutional set-up? } \\
\text { - What are the direct costs associated with the institutional set-up? }\end{array}$ \\
\hline
\end{tabular}




\section{FINDINGS}

\section{Modus operandi}

ZIMRA, a quasi-state institution, was appointed by government to collect toll fees on behalf of ZINARA. The latter is the agency responsible for the administration of the road fund as well as the coordination and monitoring the maintenance of the entire road network. ZIMRA retains $10 \%$ of revenue collected to cover its administrative expenses. In terms of the evaluation criteria in Table I above, this institutional arrangement does not promote ease of administration. There is currently no memorandum of understanding nor was ZIMRA appointed by ZINARA. Consequently, ZIMRA is not answerable to ZINARA, thereby generating avoidable transaction costs. For instance, ZINARA has accused ZIMRA of lack of transparency, late disbursement of collected revenue and corruption. These allegations were supported by the arrest of ZIMRA revenue collection personnel over revenue pilferage in October 2008 (Herald, 21 October 2009).

No toll booths have been constructed at toll sites. The system is based on a manual toll collection system consisting of rudimentary infrastructure, manned by ZIMRA personnel and the police. Zimbabwe is using the most basic version of the manual toll collection system, consisting of lane markings, demarcated by $750 \mathrm{~mm}$ plastic cones, a resting tent, and a makeshift office, as depicted in Figures 4 and 5.

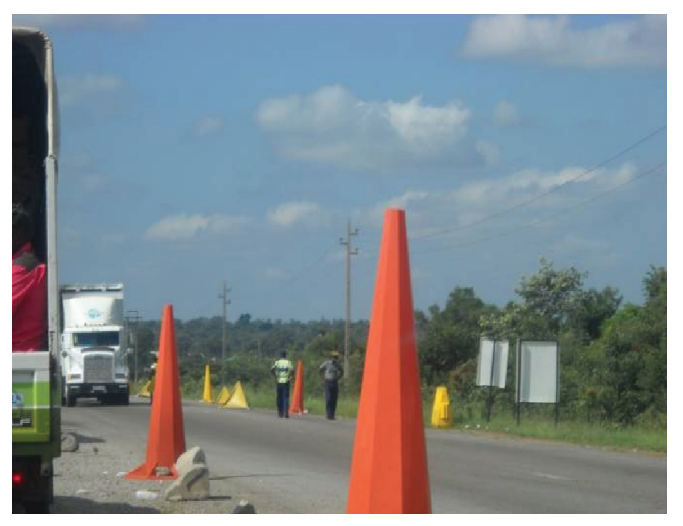

Figure 4:

Typical toll gate

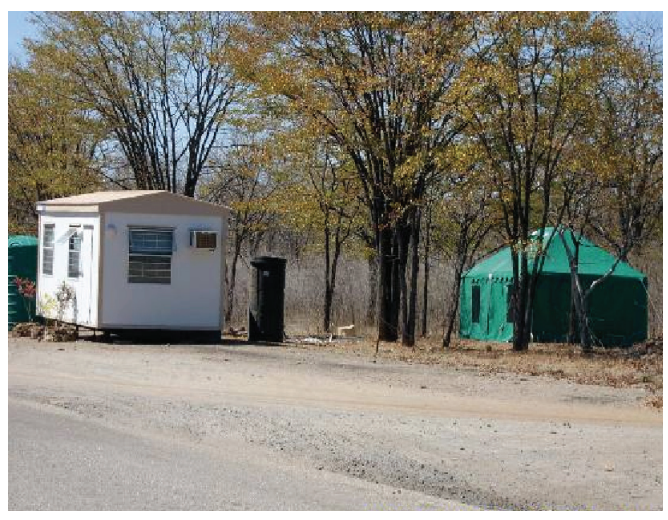

\section{Figure 5:}

Rudimentary facilities provided

In justifying the rudimentary technology and basic nature of the facilities, the minister responsible for transport argued that temporary structures would continue to be in operation in the interim until the dualisation of the highways is complete. 'We have opted for the temporary rudimentary toll gate structures because it would be foolhardy to build permanent structures when we are embarking on the dualisation of our roads,' he said.

While the tolling system shows an innovative attempt to collect revenue at the least supportive infrastructure cost, it fails to satisfy the efficiency criterion. The system is manual 
and cash-based, thereby not accommodating modern-day technology such as credit or debit cards. This situation forces motorists to carry large sums of cash in an environment associated with a severe shortage of change. Being labour-based, there are also challenges associated with fatigue, which have necessitated the deployment of more personnel. On average a toll gate is manned by four ZIMRA and five police officers. This has the net effect of raising the overhead costs. Although the $10 \%$ administrative charge retained by ZIMRA seems comparable to that in other countries such as Japan (20\%), it should be noted that the latter tolling systems are more sophisticated and costly (Fujijno, 2009). Thus, in terms of the support infrastructure outlay and scale of operation, the Zimbabwean tolling system is more costly.

In discussing technology options for toll facilities, Collier (2004) identified four alternatives, namely manual toll collection, automated coin machine collection, electronic toll collection or automatic vehicle identification and video tolling. Judging by the planning behind the toll implementation, only time will tell which toll technology the government will choose to operate. While this may have the advantage of flexibility in decision-making, it however represents a flaw in the planning and implementation process. The minister's justification, quoted above, does not really stand since road-users do not necessarily have to cover the cost of setting up toll gates. If the project had been contracted out to the private sector, this would not have been an issue, as the tolling agency would have set up their own systems without having to wait for sufficient revenue to be generated from toll fees.

In respect of toll fees, charges are pegged at US\$1 for light vehicles, US\$2 for minibuses, US\$3 for conventional buses, US\$4 for less than 10 tonne trucks and US $\$ 5$ for heavy goods vehicles of more than 10 tonnes. It is, however, notable that these rates are not based on any scientific basis, such as per kilometre charge, but rather on a gut feeling of what might be affordable to the average road-user as well as the convenience of collecting the fee. Transit vehicles with proof of payment as well as ambulances and diplomatic vehicles are exempted from paying toll fees. Government vehicles, which initially were exempted, are now required to pay. The toll fees are generally lower than South Africa's, which is the only other country that charges toll fees in the Southern African Development Community (SADC) region. For instance, according to Foresight Publications (2009), average toll fees along the N1 in South Africa are about US\$2.38 for Class I vehicles (private cars), US\$6.73 for Class II vehicles (medium heavy trucks and minibus taxis), US\$7.79 for Class III vehicles (large heavy trucks) and US\$11.93 for Class IV (extra heavy trucks). In terms of viability, the traffic volumes in South Africa are much higher than those in Zimbabwe. The Zimbabwean situation is made worse by leakages in the tolling system. Initially, tickets did not specify the vehicle types - despite the fact that toll fees were different across vehicle categories. This fault has since been addressed. It is also not uncommon for motorists to leave behind their tickets even after paying. 
According to Fujijno (2009), a number of factors determine the level and affordability of toll fees. In comparing toll fees in Japan and those of other countries, he focused on such factors as road construction costs, land prices, personnel and management requirements and level of public support (subsidies). He noted that on the basis of the above factors, toll fees in Japan are higher and less affordable as compared to those in countries such as Italy, France and South Korea.

In Zimbabwe, the determination of toll fees was done arbitrarily, based on an estimation of what the government assumed people could afford. The toll fees are generally accepted as affordable by road users, except in cases where the toll points are located within commuting radii. In the latter case, motorists are forced to pay toll fees daily. Affected households pay US\$2 daily (return trip). Given that average monthly salaries range between US\$150 and US $\$ 250$, toll charges may become unaffordable. In such circumstances the average toll fee affordability index is estimated at about $30 \%$, which makes the system largely unaffordable. At the moment there are no mechanisms to subsidise the affected commuting households. In most cases across the country, toll gates are located within the commuting radii, and hence the system largely fails in terms of the equity criterion.

Overheads of running the present system are high. Apart from ZIMRA officers, each tolling point requires the presence of policemen since by law only a uniformed police officer is authorised to stop vehicles. Observations across the country revealed that, on average, five police officers man each toll gate, in addition to at least four ZIMRA officers, per shift. Staff manning toll gates needs to be provided with transport to and from their residential areas. With three shifts per day, this translates into three return trips daily. In order to cover these costs and other administrative functions, ZIMRA retains 10\% from the revenue collected, meaning that ZINARA gets $90 \%$ of the revenue. As discussed above, $10 \%$ may appear comparable to situations in other countries. However, a closer evaluation of the operational scale and associated administrative responsibilities indicate that the Zimbabwean system is more costly.

There are no targeted dwell times at toll points besides an acknowledgement of a need to ensure minimal delay. Although observations at 12 toll gates showed average dwell times of between 20 and 50 seconds per vehicle, the toll system generally does not have standard station dwell times. Challenges such as the unavailability of change could cause delays and associated long dwell times of, at times, more than 5 minutes. For instance, it was very common for vehicles to be flagged off the road as officers sought to get change for the motorists concerned. Such a situation has a net effect of creating inefficiencies in the toll system, thereby compromising consistency in service levels. Reliability in the management of the logistics and administrative infrastructure is a critical component in ensuring effectiveness and appropriateness of road management measures. In their operational status, the toll gates create an added obstacle in a situation where speed is 
already compromised by the quality of the highways. Thus, when evaluated against the criteria above, the system fares poorly. However, it was largely concluded that most of the problems are not inherent to the system itself but a result of the wider macroeconomic situation in the country.

\section{Location of toll gates}

In locating toll gates, the adopted criteria specified that toll gates were to be situated outside urban areas and approximately $100 \mathrm{~km}$ apart. Both criteria proved to be difficult to implement. First, some people living on the outskirts of urban areas raised numerous complaints as they had to pay the toll fees daily. Consequently, the government was forced to relocate some toll gates. Secondly, the need to ferry revenue-collection personnel to and from their residential areas meant that tolling points had to be as close as possible to urban areas. These location decisions are aimed at lowering the severity of secondary costs such as utilities and staffing. However, as was highlighted above, the location of toll gates has a major impact on average household affordability, particularly on those who commute and pay fees daily. Table II below shows the location of the 22 toll-collection points as well as distances from the nearest urban centres, and Figure 6 depicts the location of the 22 tolling points.

Table II: Summary of location of toll collection points

\begin{tabular}{|c|c|c|c|}
\hline & Tolling points & Route & Distance \\
\hline 1 & Before Crocodile Motel & \multirow{2}{*}{ Harare - Mutare } & 14 km from Rusape \\
\hline 2 & After Riverside (Odzi) & & $18 \mathrm{~km}$ from Mutare \\
\hline 3 & Before Shamva turn-off & Harare - Nyamapanda & $20 \mathrm{~km}$ from Harare \\
\hline 4 & Inkomo & \multirow{2}{*}{ Harare - Chirundu } & $40 \mathrm{~km}$ from Harare \\
\hline 5 & Lions Den & & $22 \mathrm{~km}$ from Chinhoyi \\
\hline 6 & After the Norton fly-over & \multirow{2}{*}{ Harare-Gweru } & $44.5 \mathrm{~km}$ from Harare \\
\hline 7 & After Kadoma & & $14 \mathrm{~km}$ from Kadoma \\
\hline 8 & Before Eskbank Farm & Harare - Mt Darwin & 18 km from Harare \\
\hline 9 & Before Skyline & \multirow{2}{*}{ Harare - Masvingo } & $18 \mathrm{~km}$ from Harare \\
\hline 10 & Mushagashi & & $32 \mathrm{~km}$ from Masvingo \\
\hline 11 & Shurugwi & Gweru - Masvingo & $10 \mathrm{~km}$ from Shurugwi \\
\hline 12 & Sino turn-off & Gweru - Chivhu & 31 km from Gweru \\
\hline 13 & Tree Top/Somabula turn-off & Gweru - Bulawayo & 17 km from Gweru \\
\hline 14 & 22 Miles & Masvingo - Mutare & $32 \mathrm{~km}$ from Mutare \\
\hline 15 & Mashava & Masvingo - Bulawayo & $53 \mathrm{~km}$ from Masvingo \\
\hline 16 & Lutumba & \multirow{2}{*}{ Masvingo - Beitbridge } & $23 \mathrm{~km}$ from Beitbridge \\
\hline 17 & Chivi turn-off & & 45 km from Masvingo \\
\hline 18 & Before ZRP/Hotel turn-off (Figtree) & Bulawayo - Plumtree & $37.2 \mathrm{~km}$ from Bulawayo \\
\hline 19 & Naude quarry site & \multirow{2}{*}{ Bulawayo - Beitbridge } & $11.7 \mathrm{~km}$ from Beitbridge \\
\hline 20 & Before Esigodini & & 37 km from Bulawayo \\
\hline 21 & Before Nyamandlovhu turn-off & \multirow{2}{*}{ Bulawayo - Vic Falls } & $13 \mathrm{~km}$ from Bulawayo \\
\hline 22 & After Cinderella & & 6 km from Hwange \\
\hline
\end{tabular}




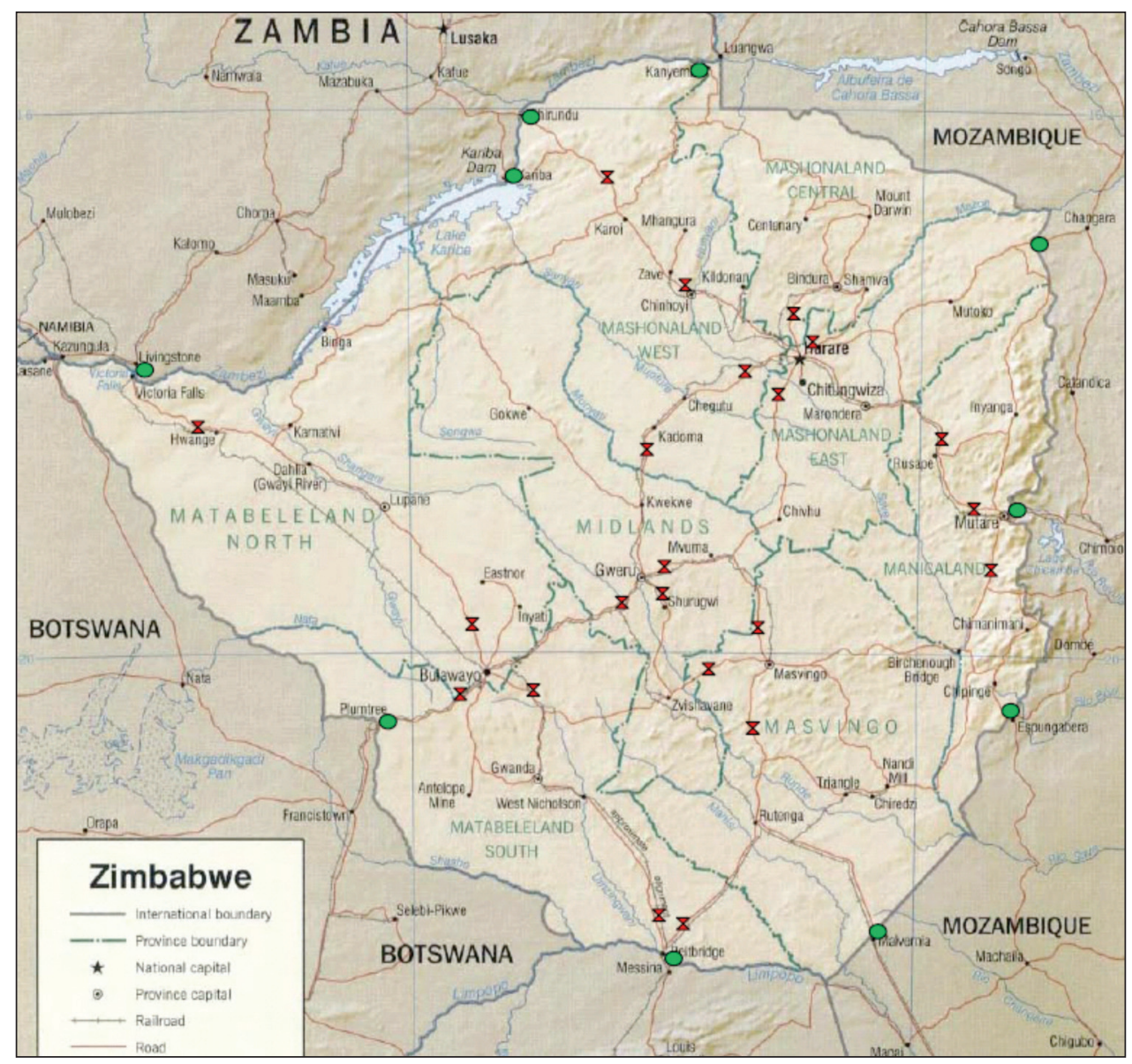

Figure 6: Zimbabwe roads map showing location of toll centres $(\boldsymbol{Z})$

\section{Traffic volumes and management}

The busiest regional trunk road in Zimbabwe is the Harare-Beitbridge road connecting to South Africa. Twenty-four-hour traffic counts that were conducted recently have indicated that a section of the Harare-Beatrice section $(55 \mathrm{~km})$, which experiences the heaviest flow, recorded just over 4000 vehicles per day. The average flows for the remaining sections of the road were around 2000 vehicles per day. Thus, vehicle flows are far below the 5000 vehicles per day, which is normally regarded as the threshold for a viable toll road.

Vehicle population in the country is relatively low. According to the Zimbabwean Central Vehicle Registry (CVR), the country has a registered vehicle population of about 850000 which equates to approximately 57 vehicles per 1000 people. The majority of these vehicles are registered in urban areas, where they are resident. In terms of the traffic density indicator, the number of vehicles equates to about 10 vehicles per kilometre for the entire road network. From this, it is clear that in the case of Zimbabwe, there is no noticeable congestion on the trunk roads network. Thus, traffic management cannot be a justification for introducing toll roads. 
The volumes of traffic passing through the 22 toll gates along the regional trunk roads for the period 11 September to 16 December 2009 are provided in Table III below.

Table III: Traffic flows passing through toll gates

\begin{tabular}{|c|c|c|c|c|c|c|}
\hline Period & Light vehicles & Minibuses & Big buses & Lorries & $\begin{array}{c}\text { Heavy goods } \\
\text { trucks }\end{array}$ & Total \\
\hline 11-30 Sep 2009 & 512370 & 32368 & 26603 & 27492 & 52735 & 651568 \\
\hline 01-31 Oct 2009 & 791186 & 69960 & 41387 & 41523 & 81346 & 1025402 \\
\hline 01-30 Nov 2009 & 774415 & 70679 & 40389 & 40559 & 81828 & 1007870 \\
\hline 01-16 Dec 2009 & 454571 & 44109 & 23823 & 21589 & 38618 & 582710 \\
\hline Total & 2532542 & 217116 & 132202 & 131163 & 254527 & 3267550 \\
\hline
\end{tabular}

(Source: Adapted from data obtained from Ministry of Transport, Communications and Infrastructural development)

For this period, a total of 3267550 fee-paying vehicles passed through the 22 toll gates. This comprised $78 \%$ cars, $8 \%$ heavy goods vehicles (HGV) of more than 10 tonnes, 7\% minibuses, 4\% conventional buses and 3\% light trucks (less than 10 tonnes). The total number of vehicles that passed through the toll gates equates to 33682 vehicles per day, or an average of 1561 vehicles per toll gate per day. It is, therefore, evident that the average volume of traffic passing through individual gates is low. This is also consistent with evidence obtained from traffic counts cited in the preceding section of this report. Thus, in terms of the viability criteria, the toll system is not supported by sufficient traffic volumes.

Despite the low traffic volumes, the government is determined to generate as much revenue from the toll systems as possible. This will be achieved through increasing the number of toll gates across the country. The Permanent Secretary in the Ministry of Transport indicated that the current toll gates are not generating enough revenue. He indicated that there are plans to increase the number of toll gates as a way of boosting government coffers. In expressing this view he said, 'At the moment, we are collecting around US\$1.3 million a month from our 22 tolling points throughout the country. We believe if we increase these points, we are going to be able to get more funds to attend to the pressing needs of our country and infrastructure. Our view as a ministry is that these funds are not sufficient enough to cover our needs. We need more funds. We have to specifically generate resources to meet the challenges we face.' (Standard, 1 May 2010).

\section{Alternative routes and equity}

The road tolling system is aimed at capturing all traffic travelling along all major trunk roads. Tolling points are therefore located in such a way that possibilities of evasion are minimised. This makes toll fee payments compulsory since there are no alternative routes. The need 
to provide an alternative route was described by a Ministry official as 'an old idea that does not apply to Zimbabwe'. The same view was echoed by the MoTIC who said, 'There are many people who wanted us to improve the roads first. Yes, we should have done that, but we do not have the money, so we need road users to pay so that we can use the money to repair roads.' (Herald, 17 September 2009).

The above view demonstrates that the tolling programme is a revenue-centred strategy as opposed to one intended to improve the road network service levels. Dismissing the alternative route principle defeats a toll system's needs to create choice and equity among road users. Road users have different affordability levels. Therefore, denying them the choice creates an unequal transportation system that does not distribute costs and benefits equally to all segments of the population within the service areas. There is, thus, no provision for affordable transportation to low-income individuals.

The rigid nature of the policy has resulted in adverse reaction from some communities and the motoring public. According to the Voice of America (VOA), 27 August 2009, some Zimbabwean motorists are avoiding toll gates along the country's major highways by using alternative dirt roads. Some of these roads were hastily cleared by unemployed youths who are charging a small fee per vehicle. Motorists said they preferred to use the dirt roads to paying the ZIMRA. While these arrangements are illegal, they reflect the importance of adopting the entire set of toll principles in implementing toll systems. Such makeshift toll structures create undesired revenue leakages.

\section{Tolling system challenged}

A Bulawayo resident sued the Ministry of Transport, Infrastructure and Communication, Zimbabwe Revenue Authority and City of Bulawayo as first, second and third respondents respectively over the location of a toll gate located on the $13.5 \mathrm{~km}$ peg on the BulawayoVictoria Falls road. His argument was that he is forced to pay toll fees daily by virtue of the location of his plot which is within the jurisdiction of the City of Bulawayo. He further noted that the responsible minister failed, as required by the Road Act to consult the local authority in whose area of jurisdiction the toll gate was located. The applicant was supported by the residents' association of his area which argued that the location of the toll gate was a breach of their constitutional rights to freedom of movement, association and assembly.

In his judgment, the judge concurred with the applicant's argument and ordered the toll gate to be relocated. This case shows lack of proper planning on the part of the responsible authorities. It may also set a precedent, opening up a floodgate of challenges by others who are similarly affected. 


\section{Revenue generation and use}

From 11 September to 16 December 2009, the cumulative revenue generated amounted to US\$5 180980 . This translates to US\$53 416 per day or US\$2 428 per toll gate daily. According to the Ministry of Transport and Communication, an average of US\$1.3 million is collected monthly across the country. Revenue contribution by each vehicle category was $49 \%$ for cars, $25 \%$ for $\mathrm{HGVs}, 10 \%$ for lorries and for conventional buses and minibuses $8 \%$ each. The levels of contribution are a reflection of the fees payable per vehicle category, as well as the traffic volumes that pass through the tolling points.

Revenue flows could have been improved with proper strategies to minimise leakages. For instance, initially, there was one common ticket for all categories of vehicles, although in reality they were paying different amounts. The ticket did not have any information showing the amount and type of vehicle. This meant that a ticket issued to an HGV, paying US\$5 could easily be accounted for as one issued to a light vehicle, which paid US\$1. It was also observed that some impatient drivers paid the required amount but never bothered to collect their receipts. In such cases, the declaration of charges, where receipts are not collected by road users, then depended on the integrity of the collection officer. Some leakages were also a result of new illegal alternative roads which were discussed earlier.

Revenue leakage was also exacerbated by the number of vehicles that are exempted. From 11 September to 16 December 2009, 357108 vehicles or 11\% of the total traffic volumes that passed through the toll gates were exempted. This is a high proportion, which clearly shows that a considerable amount of revenue is not being collected. Interestingly, according to The Herald issue of 6 December 2009, apart from the vehicles that are officially exempted, some government officials and Members of Parliament were also reportedly refusing to pay, clearly abrogating their own policies. In order to minimise revenue leakage as well as verify the amounts which are collected by ZIMRA, as of 31 August 2009, ZINARA started conducting independent traffic counts at 16 locations, within the vicinity of selected toll gates. The traffic counts were conducted randomly, independent of ZIMRA. The traffic counts would be used to verify the revenue collected against the recorded traffic volumes. Ultimately, this would show the existence and magnitude of leakages.

The question of whether the revenue generated is going to be used for road maintenance or diverted elsewhere is a critical one. Since this is the first time a road-pricing strategy has been implemented in Zimbabwe, the general public has viewed it with a lot of suspicion. There are no local projects against which the current toll programme can be benchmarked or modelled on. The authenticity of the road tolling system is still questioned by the general public who are concerned that the money raised would be diverted elsewhere and not used as a dedicated road fund. Previous experiences with the AIDS and Drought Relief levies were cited as examples where money raised was diverted away from the intended 
purposes. Therefore, the view of many people is that this new programme is just a way of milking money from motorists, under the guise of the need to fund road maintenance.

These suspicions have been buttressed by the fact that, while toll systems in most countries are privately administered on a BOT basis, the Zimbabwean Government has opted for an entirely state-controlled toll system. A state institution, the ZIMRA, is responsible for collecting the toll fees. As one member of public explicitly explained, 'We hope that the toll gates fees will not be another form of Government fund-raising exercise under the guise of road development' (Herald, 17 September 2009).

Only a few months have elapsed since the introduction of road tolls in Zimbabwe at the time of writing this paper. This is a very short time in which to ascertain any long-term trends on the use of revenue being generated from road tolls. However, there are some present indicators that can be scrutinised in order to evaluate whether the revenue would be used to improve the roads or diverted elsewhere.

The MoTIC has given an assurance on the use of revenue generated. In expressing this, the Minister said, 'What we want to emphasise to the motoring public is that the money is not going to be used for any other purposes save for the rehabilitation and maintenance of the country's roads' (Herald, 10 September 2009). This assurance was backed by the revenue distribution mechanisms that were put in place. The money collected is transferred directly to the ZINARA account without going through the Exchequer. This is a positive development compared to the traditional practice where such funds would have been channelled through the Ministry of Finance. This gives assurance to the public of the likelihood that the money collected will be dedicated to the improvement of the country's road infrastructure. There are, however, allegations that some local authorities, which were allocated part of the toll revenue by ZINARA, diverted the money to other pressing administrative uses.

\section{Adequacy of revenue}

It has been established that the tolling system currently generates about US\$1.3 million monthly. The annual forecast is approximately US\$19 million. Although tolling is just one of the revenue-generating methods used in Zimbabwe, overall, the amount being collected is inadequate for road maintenance. An estimated $4668 \mathrm{~km}$ of the country's roads require rehabilitation at an estimated cost of about US\$200 000 per kilometre. In 2009, road maintenance required about US\$225 million, while road rehabilitation needed approximately US\$1.3 billion. Thus, the estimated US\$16 million expected to be raised annually from toll charges is a drop in the ocean. This needs to be complemented with other innovative revenue-generating methods.

Thus, the revenue generated from toll roads needs to be assessed against other sources of revenue for road infrastructure maintenance. For a period of 10 months, up to October 
2009, approximately US\$16 million was collected from fuel levies, overload charges, transit fees and toll fees. The modal split of the total revenue according to the different sources was as follows: fuel levy (21\%), overload charges (1\%), transit fees (62\%) and toll fees (16\%). Toll fees were relatively the biggest contributor, since revenue had been collected for approximately two-and-a-half months (73 days), whereas the amounts from other sources were for 10 months (304 days). This has already begun to show as the tolling system has been implemented over the past nine months. Annually, a total of US\$31 628000 is expected to be raised from all the sources. The projected contribution of each source is as follows: fuel levy (\$4 032000$)$, overload charges ( $\$ 192000)$, transit fees ( $\$ 11904000)$, and toll fees (\$15 500 000) equating to approximately $50 \%$ of total revenue.

The estimated $\$ 31628$ million that can be raised from all the sources of revenue still falls short of the required amount required to rehabilitate the badly deteriorated road network in Zimbabwe. However, the tolling system contributes the greatest amount of revenue of approximately $50 \%$. Therefore, notwithstanding the inability of total revenue to meet the road rehabilitation requirements, the tolling system is raising a significant amount of takings when compared to other sources of revenue. There is scope to increase tolling revenue if the leakages discussed in the preceding section are addressed. There is also a need to explore other innovative approaches such as the various forms of private-public partnerships (PPPs).

\section{Impact on environment}

Although no scientific measurement was done, a visual inspection showed that oil leaks and air pollution were a major issue at toll points. Oil leaks which can be seen as dark patches on the tarmac and the roadside have not been planned for as there are no drains to capture and channel them to oil separators. This basic pollution management measure, as required by the Environmental Management Act (EMA, Act 2004), has not been fulfilled at all the toll facilities. Oil leaks are generally an issue in all areas with barriers that stop the traffic flow because the continued accumulation of oil effluent will affect the bio-systems of areas where the toll gates are located. Air pollution from idling traffic at the toll gates is another environmental threat. This affects mostly the officials manning the toll stations and residents of nearby communities. In the long term the pollution may negatively impact land values and aesthetics of the areas near toll gates. Thus, when evaluated against the criteria above, the tolling system does not fare well in environmental terms. Although it can be argued that the system is currently only makeshift, globally transportation projects are required to satisfy environmental sustainability. The nature of the project does not exempt it from scrutiny in terms of short- and long-term environmental damage. Since the tolling programme is on a national scale, a limited Environmental Impact Assessment (EIA) would have highlighted the current challenges and recommend mitigation measures. 


\section{Safety}

The makeshift structures at toll gates are not ideal, especially during the rainy season and at night. With heavy rains, revenue-collection officers are forced to abandon the tolling points resulting in some motorists going through without paying the requisite fee. When evaluated against the criteria above, the toll gates do not meet life safety requirements. Apart from exposure to environmental problems cited above the officers manning the gates also risk being run over by vehicles, especially at night. Although there is an average of five armed police officers at each toll gate, this does not eliminate the risk of security. There are no proper cash-handling facilities on site, as all the facilities are makeshift. Currently, there has been no attempt to comply with planning and/or building standards as required by the country's local and regional authorities. However, construction activities are visible at most toll sites as arrangements to comply with building standards are being effected.

\section{DISCUSSION}

This section provides a critique of other important issues that were not covered in the preceding sections.

\section{Assessment of the 'do nothing' alternative}

It is important in discussing the toll road system to assess the feasibility of maintaining the current road construction and maintenance funding methods. This is important in providing critical insights into the feasibility of alternatives. An understanding of the planning environment enhances the appreciation of the limitations faced by the planning authority. The latter is an element which is essential in ensuring objectivity when critiquing the adopted measures.

In assessing the 'do nothing' alternative the following questions are pertinent:

- Would it have been worthwhile for the government not to introduce the toll system?

- Would there have been any hope for stopping the rapid decline in road quality by maintaining the status quo?

- Is it prudent to continue depending on the current revenue generation and allocation approaches?

If the answer to the questions posed is 'yes', it follows that introducing the toll system could cause more harm than its intended benefits. On the contrary, if the answer to the questions is 'no', there is scope to consider the tolling approach as an alternative revenuegeneration strategy. However, whether the strategy is a 'silver bullet' to solving the host of road problems is questionable. For the purposes of this paper, the authors have taken a position that traditional road-funding methods are not a sustainable alternative. The pretoll programme allocation strategy depicts a situation with inadequate capacity to ensure the road assets are sustained in the future. 
From the research it was noted that the loss in road asset value was a cause for political and social concern. The 'do nothing' strategy was hugely unpopular among those interviewed. Road users felt that there was need for an intervention strategy that was designed to stop the rapid deterioration of the road network, preserve the existing basic structure and guarantee the serviceability of the road for another prolonged period.

It can thus be said, at the level of a concept and compared to the available alternatives, the scope for a toll strategy was reasonable for Zimbabwe and the situation it was in. The same however, cannot be said of the manner and style of implementation of the project, which is discussed in the next section.

\section{System design, construction and implementation}

The design of Zimbabwe's toll system did not follow a regular or rational approach as expected in a policy measure of this nature. In assessing ministerial statements, it can be concluded that the state of roads was so dire that engaging in planning procedures was largely considered not to be critical and was an unnecessary waste of time. The priority was to put in place a mechanism that could assist in generating the much-needed revenue. Therefore, the government was forced to adopt an incremental approach which presented a potential to yield immediate results. Thus, ZIMRA was requested to set up a toll gate at Skyline tollgate, approximately $18 \mathrm{~km}$ outside Harare along the Harare-Masvingo highway, to demonstrate whether the system worked. The results were considered adequate to inform and guide the implementation programme. While this was convenient, it largely negated the success factors considered critical in toll policy implementation. It failed to address strategic questions such as:

- Where do we locate the toll gates?

- How much revenue should we expect?

- What toll fee should we charge?

- How many toll gates are optimal?

These issues cannot be determined on the basis of gut feeling or cursory analysis. As recommended by Khan (2009) the toll systems need to be implemented in accordance with a rational planning process. The process emphasises the need for a feasibility study in order to adequately identify and address any associated risks.

In the Zimbabwean case, there is no documented evidence of a detailed pre-project feasibility study from the MoTIC, ZIMRA and ZINARA who are the planning, implementing and maintenance authorities. There is, thus, a strategic gap in the toll project's life cycle, the consequences of which will be clear in the long term. It must be noted that, even though there is no universal framework for planning toll systems, a feasibility study would have been desirable especially in analysing the associated risks. For instance it is notable that ZIMRA hastened to implement the system without due consideration of traffic volumes along the 
tolled routes. ZINARA only embarked on a traffic-counting exercise to verify revenues from ZIMRA, well after the commencement of the project.

\section{CONCLUSION}

The introduction of toll roads in Zimbabwe represents a bold decision by the authorities as it is only the third country in Africa (after South Africa and Morocco) to operate a tolling system on the road network. The main objective was to raise money to improve roads characterised by cracked surfaces and numerous potholes. Guided by a desire for quick access to revenue, the implementation of a revenue-generating road management strategy was done following a process that deviated from the analysis of best practices.

The need to raise as much money as possible in the shortest possible time has resulted in the siting of toll gates in locations which do not provide users with alternative routes, clearly negating a traditional principle in road toll system design. Furthermore some toll gates have been sited at locations that do not have adequate traffic volumes to justify the establishment of toll facilities. These shortcomings compromise the ability of toll roads to meet the efficiency outcomes expected from implementing them. Failure to address the issue of alternative routes creates an incentive for road users to devise alternative access points or coping strategies. If these and the road-users' concerns are not addressed, they set the stage for the growth of chaotic and disruptive tendencies that will reverse the gains sought by the entire system. The use of side roads, with massive associated environmental impacts, is hardly desirable.

There are a number of operational challenges being experienced, namely, revenue leakage, mistrust between the revenue collector and the benefactor, commuting residents who pay toll charges daily, an unpalatable operating environment due to the makeshift nature of tolling gates infrastructure, and the need to convince the public that the tolling system is authentic. These challenges do not market the toll strategy to the public as a positive and contemporary road management strategy.

Public confidence in a toll system is a crucial element in an era where the 'customer is king' and service levels are measured based on customer satisfaction levels. Thus far, the focus of the toll system has been more about how it benefits the agencies managing the roads than how they will improve roads for the people. The design and implementation of the toll system indicates a need to fill the coffers of the road authorities. Presumably a decision will be made when the money is available. While this may sound prudent, it exposes the 'new money' to more pressing demands that may crop up in a situation when the government desperately needs cash. 
The toll system aggregates all revenues from the individual toll gates. This move will subsidise the poorer performing toll gates and divert revenue away from the busiest roads. Further, by allocating revenues from toll roads to local authorities, chances are very high that revenues will be used to maintain roads that are not being tolled. This will overstretch the capacity that limited revenues can achieve, resulting in less than comprehensive repair and maintenance of strategic roads.

There is no doubt that the tolling system is contributing immensely towards raising the muchneeded revenue. In the absence of pre-determined revenue targets, any revenue achieved is a major improvement. The fact that the tolling system is generating the highest amount of revenue compared to other sources shows its potential in the long run. Notwithstanding the technical and administrative challenges experienced in the implementation of the tolling system, the intervention needs to be applauded as a bold step towards a comprehensive strategy that will bring about a more sustainable road maintenance programme. 


\section{REFERENCES}

Coleman, L. 2006. Toll roads tip to privatisation. www.csg.org, pp. 19-21.

Collier, T. 2004. Case study analysis of mid-size; urban/rural area toll road options. Technical Summary Report - Loop 49.

Fishbein, G. \& Babbar, S. 1996. Private financing of toll roads. RMC Discussion Paper Series 117, September 29, 2005.

Foresight Publications. 2009. Toll road tariffs. http://www.foresightpublications.co.za/ Tollroads.html.

Fujijno, T. 2009. Expressway in Japan - Toll road system and status. NEXCO.

Government of Zimbabwe. 2009. Statutory Instrument 39 of 2009 cited as the Toll Roads (Regional Trunk Road Network (Amendment) Regulations No 1.

Gumbie, M. E. \& Kudenga, N. 2009. Rehabilitation of Zimbabwe's surfaced road network. Paper presented at the Institute of Engineers, 2 October 2009, Zimbabwe.

Gwilliam, K. M. \& Shalizi, Z. M. 1996. Road funds, user charges and taxes. World Bank. http://www.fitchratings.com/jsp/sector/Sector.faces.

Jones, J. R. \& Bekmez, S. 2001. User charges and cost recovery: The state of Idaho/ American trucking association case. Proceedings of the 36th annual conference of the Canadian transportation Research Forum, pp. 828-43.

Khan, A. M. 2009. Risk factors in toll road life cycle analysis. Carleton University, Ottawa, Ontario K1S5B6 Canada.

Kuang, T. \& Shladover, S. 2006. Analysis of vehicle positioning accuracy requirements for communication-based cooperative collision warning. Journal of Intelligent Transportation Systems, Vol. 10, Issue 3 September 2006, pp. 131-40.

Metschies, G. \& Rausch, E. 1991. Financing road maintenance in West Africa, GTZ.

National Department of Transport. 2009. National Transport Master Plan 2005-2050. Status Quo Report Phase 1. 
Parasibu, M. 2005. The role of toll roads in promoting regional development: Private sector participation: A case study of Jabotabek. www.sustainabledevelopment.org.

Poole, R. W. \& Moore, A. 2006. Issues in road pricing for networks. Paper prepared for the Transport Research Board, p. 1.

Queiroz, C., Rdzanowska, B., Garbarczyk, R. \& Audige, M. 2008. Road user charges: Current practices and perspectives in Central and Eastern Africa. World Bank.

Silva, G. F. 2000. Toll roads: Recent trends in private participation. Word Bank Public Policy for the Private Sector, Note number 224.

Spry, J. \& Crowley, J. 2004. Assessing the impact of monopoly toll road service areas. Eastern Economic Journal, Bloomsburg, pp. 393-409.

The Herald newspaper. Issues: 10 September 2009, 17 September 2009, 21 October 2009, 6 December 2009.

The Standard newspaper. Issue 1 May 2010. http://www.thestandard.co.zw/.

The World Bank. 2006. Zimbabwe: Infrastructure assessment note for roads, railways and water sectors - draft final report, April 2006, Harare, Zimbabwe.

Yang, J. \& Qui Qui. 2005. The external factors for the practice of toll highway systems. China - USA Business Review Vol. 4 No. 7 ISSN 1537 1514, USA. Beijing Jiaotong University.

Table of acronyms

\begin{tabular}{|l|l|}
\hline AVI & Automated Vehicle Identification \\
\hline BOT & Build Operate Transfer \\
\hline CVR & Central Vehicle Registry \\
\hline HGV & Heavy Goods Vehicle \\
\hline PPPs & Private-Public Partnerships \\
\hline MoTIC & Ministry of Transport, Infrastructure and Communications \\
\hline NDoT & National Department of Transport \\
\hline PSIP & Public Sector Investment Programme \\
\hline SADC & Southern African Development Community \\
\hline ZIMRA & Zimbabwe Revenue Authority \\
\hline ZINARA & Zimbabwe National Roads Authority \\
\hline
\end{tabular}

